July 2012

\title{
Giant cell reparative granuloma of temporal bone: Case report of a 62-year-old male
}

\author{
Muhammad Waqas \\ Naeem Sultan Ali \\ Aga Khan University \\ Muhammad Zubair Tahir \\ Aga Khan University \\ Syed Ather Enam \\ Aga Khan University \\ Zeeshan-ud-din \\ Aga Khan University \\ See next page for additional authors
}

Aga Khan University, muhammad.waqas@aku.edu

Follow this and additional works at: https://ecommons.aku.edu/

pakistan_fhs_mc_surg_otolaryngol_head_neck

Part of the Otolaryngology Commons, $\underline{\text { Pathology Commons, and the Surgery Commons }}$

\section{Recommended Citation}

Muhammad Waqas, ., Ali, N. S., Tahir, M. Z., Enam, S. A., Zeeshan-ud-din, ., Ikram, M. (2012). Giant cell reparative granuloma of temporal bone: Case report of a 62-year-old male. Journal of Cranio-Maxillary Diseases, 1(2), 137-140.

Available at: $\mathrm{https}: / /$ ecommons.aku.edu/pakistan_fhs_mc_surg_otolaryngol_head_neck/38 
Authors

Muhammad Waqas, Naeem Sultan Ali, Muhammad Zubair Tahir, Syed Ather Enam, Zeeshan-ud-din, and Mubasher Ikram 


\section{Giant cell reparative granuloma of temporal bone: Case report of a 62-year-old male.}

Article · December 2012

DOI: $10.4103 / 2278-9588.105709$

CITATIONS

0

6 authors, including:

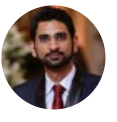

\section{Muhammad Waqas}

Aga Khan University Hospital, Karachi

52 PUBLICATIONS 34 CITATIONS

SEE PROFILE

Syed Ather Enam

Aga Khan University Hospital, Karachi

107 PUBLICATIONS 948 CITATIONS

SEE PROFILE
READS

29
Naeem Sultan Ali

The Aga Khan Hospital, 17 PUBLICATIONS 59 CITATIONS

SEE PROFILE

Some of the authors of this publication are also working on these related projects:

Project High Intensity Focused Ultrasound View project

Project Endovascular neurosurgery View project 


\title{
Giant cell reparative granuloma of temporal bone: Case report of a 62-year-old male
}

\author{
Muhammad Waqas, Naeem Sultan Ali', Muhammad Zubair Tahir, Syed Ather Enam, Zeeshan-ud-din², \\ Mubasher Ikram ${ }^{1}$
}

Departments of Neurosurgery, ${ }^{1}$ Otorhinolaryngology, and ${ }^{2}$ Pathology, Aga Khan University Hospital, Karachi, Pakistan

\section{ABSTRACT}

Giant cell reparative granuloma (GCRG) is an uncommon non-neoplastic reactive tumor which occurs almost exclusively within the mandible and maxilla. GCRG of the temporal bone is a rare condition. It has been found to affect predominantly adolescents and adults (age: 10-25 years). We report a case of a 62-year-old male with GCRG of left temporal bone who presented to us with progressive left temporal swelling for 3 months. It was associated with hearing loss. There was no history of trauma. A non-contrast computed tomography scan brain showed a locally destructive lesion involving squamous temporal bone closely related to the left temporal lobe and infratemporal fossa. Magnetic resonance imaging brain with contrast showed a hypointense lesion on T1 and with peripheral contrast enhancement after gadolinium injection. Patient underwent left temporal craniotomy with atticotomy, mastoidectomy, duraplasty, and opening of middle ear and temporomandibular joint. A bone graft was then taken from right iliac crest and used to repair the resulting defect. Final histopathology report confirmed GCRG. We discuss radiological and histopathological features of lesion in this case report.

Keywords: Benign lesions of skull, giant cell reparative granuloma, temporal bone

\section{INTRODUCTION}

Giant cell reparative granuloma (GCRG) is an uncommon non-neoplastic reactive tumor which occurs almost exclusively within the mandible and maxilla. Cases involving the skull are few. GCRG of the temporal bone is exceedingly rare with so far less than 20 cases reported in the international medical literature. It has been found to affect predominantly adolescents and adults (age: 10-25 years) with a male to female ratio of $1: 2$. Although regarded as a benign process, it can behave aggressively, and surgical excision has been advised whenever

\begin{tabular}{|l|l|}
\hline \multicolumn{2}{|c|}{ Access this article online } \\
\hline Quick Response Code: & Website: \\
\hline & www.craniomaxillary.com \\
\cline { 2 - 2 } & DOI: \\
\hline
\end{tabular}

possible. ${ }^{[1]}$ We report a case of a 62-year-old male with GCRG of left temporal bone.

\section{CASE REPORT}

A 62-year-old male presented to us with a history of progressive left temporal swelling for 3 months. His comorbids included hypertension and obstructive sleep apnea. The swelling was associated with decreased hearing in left ear. He could not recall any history of trauma. On examination, there was sagging of left external auditory canal, with ipsilateral conductive hearing loss. Swelling was non-fluctuant, non-tender, and $4 \times 3 \mathrm{~cm}$ in dimension. There was no facial palsy.

A non-contrast computed tomography (CT) scan brain [Figure 1] showed a locally destructive lesion involving squamous temporal bone closely related to the left temporal lobe and infratemporal fossa. Magnetic resonance imaging (MRI) brain

\section{Correspondence to:}

Dr. Syed Ather Enam, Department of Neurosurgery, Aga Khan University Hospital, P.O. Box 3500, Stadium Road, Karachi 74800, Pakistan.

E-mail: ather.enam@aku.edu 
Waqas, et al.: Giant cell reparative granuloma of temporal bone: Case report of a 62-year-old male

with contrast showed a hypointense lesion on T1 and with peripheral contrast enhancement after gadolinium injection [Figure $2 a$ and b]. It showed extension up to temporal lobe causing extra-axial compression.

Inconclusive fine needle aspiration cytology was followed by an incisional biopsy which showed high suspicion of chronic GCRG. Patient underwent left temporal craniotomy with atticotomy, mastoidectomy, duraplasty, and opening of middle ear and temporomandibular joint. A bone graft was then taken from right iliac crest and used to repair the resulting defect. Intraoperatively, lesion was found to be soft avascular infiltrating temporalis, middle skull fossa, with intradural extension and extension

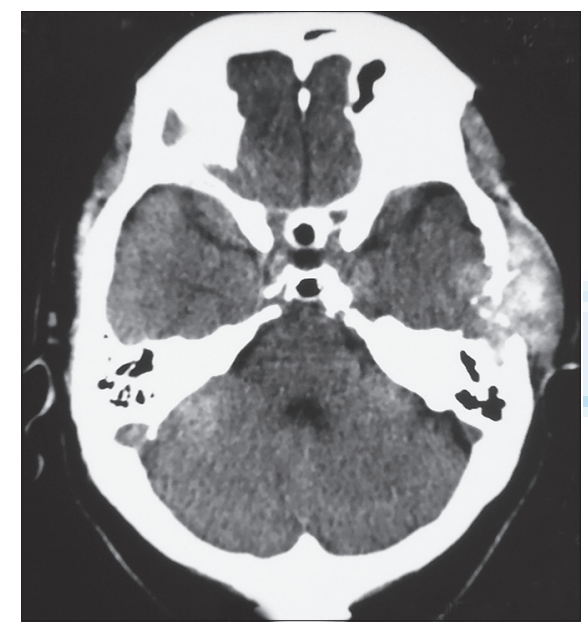

Figure 1: A non-contrast computed tomography scan axial image showing a locally destructive temporal bone lesion

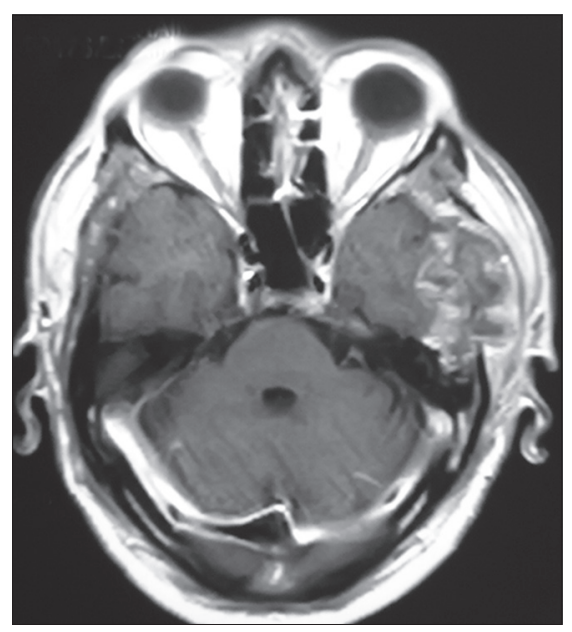

Figure 3: Post-contrast pre-operative Magnetic resonance axial image into infratemporal fossa. However, there was no involvement of brain parenchyma.

Post-operatively, patient remained well. There was no post-operative deficit and his left sided conductive loss improved. Histopathology report showed tissue containing sheets and aggregates of plump to oval cells having abundant eosinophilic cytoplasm and rounded nuclei with scattered multinucleated giant cells with hemosiderin-laden macrophages [Figure 3]. On immunohistochemistry, CD68 maker was also found positive [Figure 4]. Mitotic figures were occasional. Slides were reviewed with several histopathologists and diagnosis of central chronic GCRG was made.

At three months follow-up, MRI with contrast did not show any recurrence [Figure 5]. He complains of mild discomfort on opening up of jaw for which jaw exercises are advised.
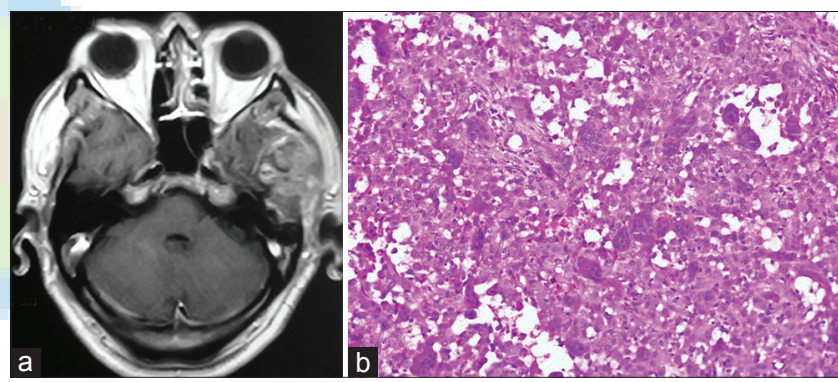

Figure 2: (a) Magnetic resonance imaging (MRI) brain with contrast showed a hypointense lesion on T1 and with peripheral contrast enhancement after gadolinium injection (b) $\mathrm{H}$ and $\mathrm{E}$ staining of tissue sample

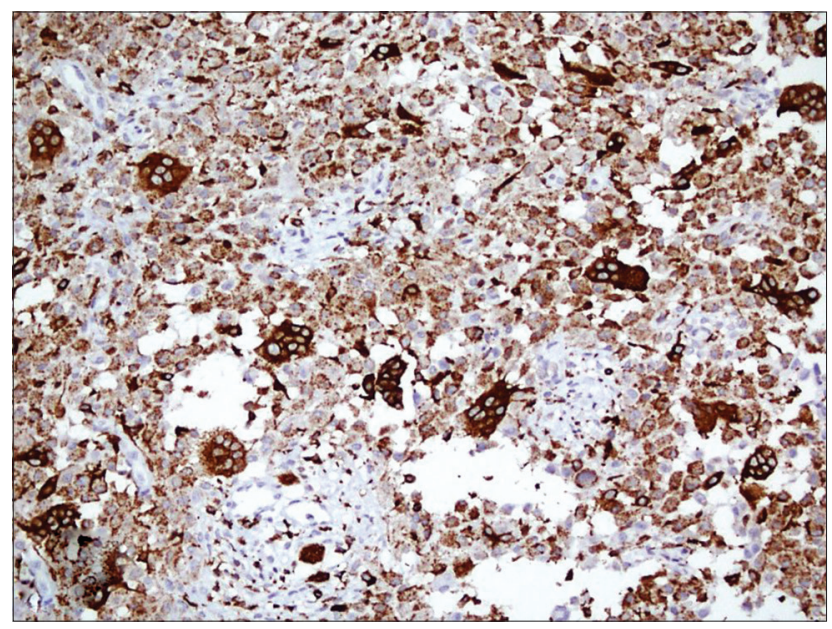

Figure 4: Immunohistochemistry for CD68 markers 
Waqas, et al.: Giant cell reparative granuloma of temporal bone: Case report of a 62 -year-old male

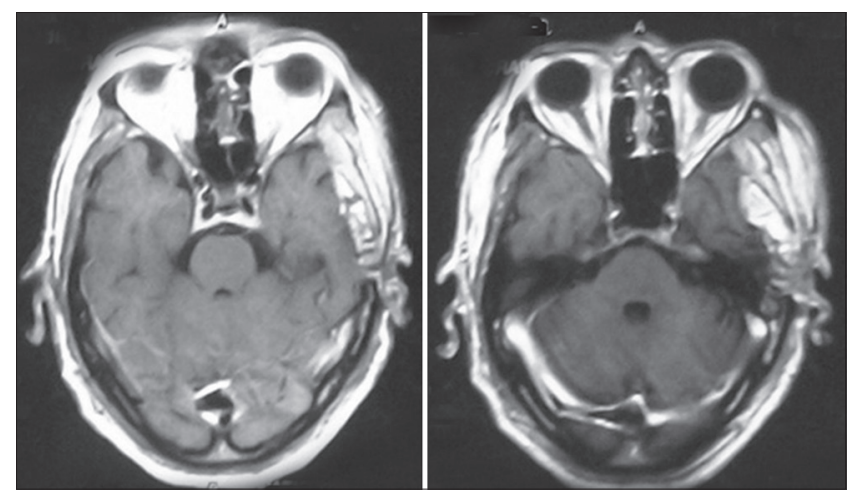

Figure 5: Post-operative magnetic resonance imaging axial images with contrast

\section{DISCUSSION}

GCRG is a rare benign granulomatous lesion, which is postulated to be a result of an exacerbated reparative process related to previous trauma and intraosseous hemorrhage. It is more frequently seen in mandibular or maxillary regions, ethmoid bone, sphenoid bone, and petrous temporal bone. [1] As diagnosis of GCRG is challenging, the actual frequency of this lesion in the skull base is hard to determine. Less than 20 well-documented cases have been reported in the last 35 years. ${ }^{[2]}$ Adolescents and young adults (age: 10-25 years) are more prone with a male to female ratio of $1: 2$. In a few cases, a definitive history of trauma prior to the development of GCRG is noted but many authors consider a traumatic etiology unlikely. ${ }^{[3]}$ Clinical features depend on the site of the bony involvement and compromise of the nearby neurovascular structures. Initially localized pain, initially a localized pain, and then diffuse swelling followed 1-2 weeks later by a rapid progressive well localized swelling with or without the features of raised intracranial pressure and cerebral compression. Involvement of the ethmoid bone results in nasal symptoms, whereas sphenoid bone involvement produces orbital symptoms (mainly diplopia) and the petrous temporal bone involvement causes hearing deficits, vertigo, tinnitus, giddiness, and facial paresis.

Plain radiographs often show expansion of the bone with thinning of the cortex by a well-demarcated multiloculated radiolucent lesion. On CT, an isoattenuation or a mixed attenuation osteolytic bone lesion with compression of the brain or orbital contents is usually visualized. The MRI scan shows an isointensity or a mixed intensity mass lesion on the $T 1$-weighted images with mild enhancement on intravenous administration of gadolinium, whereas the T2-weighted images show an non homogenous hypointense or isointense lesion. ${ }^{[4]}$

Histological examination in GCRG shows the stroma mainly formed by the abundant spindleshaped fibroblastic cells and small giant cells with a few nuclei around the hemorrhagic foci. There are no features suggestive of malignancy. In the differential diagnosis of GCRG, the other giant cell containing lesions, i.e., giant cell tumor of the bone, an aneurysmal bone cyst, and a brown tumor of the hyperparathyroidism should be considered. GCRGs have a very similar radiographic appearance to giant cell tumor (GCT). Differentiation between the two largely depends upon the histological location and shape of giant cells. The presence of osseous metaplasia favors a diagnosis of GCRG. The presence of hemosiderin pigment is thought to be one of the most important findings that differentiate GCRG from GCT because perivascular hemorrhage and hemosiderin deposition are believed to occur to a lesser extent in GCT than in GCRG.

Management of GCRG is mainly a microsurgical excision as with curettage alone, recurrence occurs in about $15 \%$ of cases. Malignancy and metastasis have not been reported in GCRG. ${ }^{[3]}$ In cases of incomplete surgical removal, post-operative radiation should be considered. ${ }^{[1]}$ Due to the complexity of vital structures at the skull base, complete surgical excision may be sometimes impossible in this anatomic region. Therefore, primary radiotherapy has been recommended when the GCRG is not amenable to surgery. However, radiotherapy is reported to be less effective and to carry the risk of sarcomatous induction. ${ }^{[1]}$ Because of potential recurrence and aggressive growth behavior, treatment strategies can be challenging and regular clinical and radiological follow-up investigations are indispensable. ${ }^{[5]}$

There was no history of trauma in our patient. GCRG at this age has not been reported before. We also had a pre-operative incisional biopsy of the lesion which provided a very important hint as to the nature of lesion and management plan. To remove the disease process completely, temporomandibular joint (TMJ) had to be opened and this has led to mid-post-operative discomfort. Graft used from iliac crest helped to repair the defect created by excision 
Waqas, et al.: Giant cell reparative granuloma of temporal bone: Case report of a 62-year-old male

of lesion. We could not find a lot of examples using bone graft in cases of excision of GCRG lesions.

\section{CONCLUSION}

GCRG is a rare entity thought to be related to trauma relatively more common in adolescents and young adults especially females. We describe its incidence in an elderly male with no history of trauma and involving more of squamous than petrous temporal bone.

\section{REFERENCES}

1. Boedeker CC, Kayser G, Ridder GJ, Maier W, Schipper J. Giantcell reparative granuloma of the temporal bone: A case report and review of the literature. Ear Nose Throat J 2003;82:926-27.

2. Menge M, Maier W, Feuerhake F, Kaminsky J, Pfeiffer J.
Giant cell reparative granuloma of the temporal bone. Acta Neurochir (Wien) 2009;151:397-9.

3. Plontke SK, Adler CP, Gawlowski J, Ernemann U, Friese SA, Plinkert PK. Recurrent giant cell reparative granuloma of the skull base and the paranasal sinuses presenting with acute one-sided blindness. Skull Base 2002;12:9-17.

4. Kim HJ, Lee HK, Suh DC, Choi CG, Kim JK, Lee JH, et al. Giant cell reparative granuloma of the temporal bone: MR findings with pathologic correlation. AJNR Am J Neuroradiol 2003;24:1136-8.

5. Souter MA, Bird PA, Worthington JP. Giant cell reparative granuloma of the temporal bone treated with calcitonin. Otol Neurotol 2006;27:999-1002.

How to cite this article: Waqas M, Ali NS, Tahir MZ, Enam SA, Z, Ikram M. Giant cell reparative granuloma of temporal bone: Case report of a 62 -yearold male. J Cranio Max Dis 2012;1:137-40.

Source of Support: Nil. Conflict of Interest: None declared.

Submission: July 10, 2012, Acceptance: September 30, 2012

\section{New features on the journal's website}

Optimized content for mobile and hand-held devices

HTML pages have been optimized for mobile and other hand-held devices (such as iPad, Kindle, iPod) for faster browsing speed.

Click on [Mobile Full text] from Table of Contents page.

This is simple HTML version for faster download on mobiles (if viewed on desktop, it will be automatically redirected to full HTML version)

\section{E-Pub for hand-held devices}

EPUB is an open e-book standard recommended by The International Digital Publishing Forum which is designed for reflowable content i.e. the text display can be optimized for a particular display device.

Click on [EPub] from Table of Contents page.

There are various e-Pub readers such as for Windows: Digital Editions, OS X: Calibre/Bookworm, iPhone/iPod Touch/iPad: Stanza, and Linux: Calibre/Bookworm.

\section{E-Book for desktop}

One can also see the entire issue as printed here in a 'flip book' version on desktops.

Links are available from Current Issue as well as Archives pages.

Click on $\sqrt{\mathrm{e}}$ View as eBook 